\title{
A Meaningful Opportunity to Comply
}

\author{
Abigail West ${ }^{*}$
}

\section{INTRODUCTION}

In the fight against trademark infringement, brand owners have in recent years adopted a new tactic: bringing suit against the individuals responsible for the manufacture and sale of counterfeit goods. ${ }^{1}$ Because defendants in these lawsuits sometimes fail to appear in court, plaintiffs instead seek the profits made by these counterfeiters as a remedy. ${ }^{2}$ In several recent cases, luxury brands Tiffany and Gucci have done just this. As part of discovery, Tiffany and Gucci requested several defendants' bank records from Chinese-owned banks to determine the profits made by the defendants. ${ }^{3}$ The banks challenged these discovery requests, forcing the courts to address whether the Hague Convention on Taking Evidence Abroad in Civil or Commercial Matters (Hague Evidence Convention) or the Federal Rules of Civil Procedure (Federal Rules) should be used to order evidence disclosure from non-party Chinese banks. ${ }^{4}$

The seminal Supreme Court case on the issue of discovery abroad is Societe Nationale Industrielle Aerospatiale v. United States District

\footnotetext{
* J.D. Candidate 2015, University of Kansas School of Law. B.A. 2003, University of Kansas. I would like to thank Professor Ellen Sward for her invaluable feedback without which this comment would not have been possible. I would also like to thank the Kansas Law Review board and staff for all of their hard work.

1. Minning Yu, Note, Benefit of the Doubt: Obstacles to Discovery in Claims Against Chinese Counterfeiters, 81 FORDHAM L. REV. 2987, 2996-98 (2013).

2. Id. at 2990-91, 2997-98. The Lanham Act establishes civil remedies for trademark violations, including recovery of the defendant's profits. 15 U.S.C. $§ 1117$ (2012). The Act authorizes the seizure of "records documenting the manufacture, sale, or receipt of things involved in such violation," which may then be used by the plaintiff to prove the defendant's sales. Id. §§ 11161117.

3. Tiffany (NJ) LLC v. Qi Andrew, 276 F.R.D. 143, 145-46 (S.D.N.Y. 2011); Gucci Am., Inc. v. Weixing Li, No. 10 Civ. 4974, 2011 U.S. Dist. LEXIS 97814, at*1-2 (S.D.N.Y. Aug. 23, 2011); Tiffany (NJ) LLC v. Forbse, No. 11 Civ. 4976, 2012 U.S. Dist. LEXIS 72148, at *3-4 (S.D.N.Y. May 23, 2012).

4. Tiffany, 276 F.R.D. at 152-54; Gucci, 2011 U.S. Dist. LEXIS 97814, at *22-25; Tiffany, 2012 U.S. Dist. LEXIS 72148, at*17-21.
} 
Court for the Southern District of Iowa. ${ }^{5}$ In Aerospatiale, the Supreme Court held that the Hague Evidence Convention provided optional measures for obtaining evidence abroad and did not prevent district courts from ordering foreign parties to produce evidence located abroad under the Federal Rules. ${ }^{6}$ As a result, courts are to perform a five-step comity analysis to determine whether to use the Hague Evidence Convention or the Federal Rules. ${ }^{7}$ Writing for the dissent, however, Justice Blackmun argued that the Hague Evidence Convention should be the first resort for United States courts for obtaining evidence abroad. ${ }^{8}$ According to Justice Blackmun, the Hague Evidence Convention better addresses issues of comity and national interests for both the United States and foreign states. ${ }^{9}$

The holding and method of comity analysis from Aerospatiale was employed in the aforementioned cases involving Tiffany and Gucci. ${ }^{10}$ As part of their suits, the plaintiffs-Tiffany and Gucci-requested disclosure of information regarding the defendants' bank accounts from the New York branches of several Chinese banks under the Federal Rules. ${ }^{11}$ The banks objected to disclosure of information held in their Chinese branches, claiming such disclosure would violate Chinese banking laws, and requested that the plaintiffs use the Hague Evidence Convention procedures to complete their discovery requests. ${ }^{12}$ In determining whether to use the Federal Rules or the Hague Evidence Convention, the courts used the five-factor comity analysis mentioned in Aerospatiale (along with two additional factors used in the Southern District of New York). ${ }^{13}$ The use of the comity analysis in these cases,

5. 482 U.S. 522 (1987).

6. Id. at 538

7. Id. at $544 \mathrm{n} .28$.

8. Id. at $548-49$.

9. Id. at $551-68$.

10. Tiffany (NJ) LLC v. Qi Andrew, 276 F.R.D. 143, 151 (S.D.N.Y. 2011); Gucci Am., Inc. v. Weixing Li, No. 10 Civ. 4974, 2011 U.S. Dist. LEXIS 97814, at *36 (S.D.N.Y. Aug. 23, 2011); Tiffany (NJ) LLC v. Forbse, No. 11 Civ. 4976, 2012 U.S. Dist. LEXIS 72148, at*12-13 (S.D.N.Y. May 23, 2012).

11. Tiffany, 276 F.R.D. at 145-46; Gucci, 2011 U.S. Dist. LEXIS 97814, at*1-2; Tiffany, 2012 U.S. Dist. LEXIS 72148, at *3-4.

12. Tiffany, 276 F.R.D. at 146; Gucci, 2011 U.S. Dist. LEXIS 97814, at*5-6; Tiffany, 2012 U.S. Dist. LEXIS 72148, at *5.

13. Tiffany, 276 F.R.D. at 151; Gucci, 2011 U.S. Dist. LEXIS 97814, at*15-16; Tiffany, 2012 U.S. Dist. LEXIS 72148, at *12-13. The two additional factors are the nature of the hardship and the good faith of the party resisting discovery. Tiffany, 276 F.R.D. at 151; Gucci, 2011 U.S. Dist. LEXIS 97814, at*16; Tiffany, 2012 U.S. Dist. LEXIS 72148, at*13. 
however, led to inconsistent outcomes despite similar circumstances and, in some instances, identical evidence. However, the analysis in the Tiffany cases came to the most workable conclusion: courts should "forebear from assuming that the Hague Evidence Convention is not a viable option until Chinese authorities have had a meaningful opportunity to comply with similar requests but have failed to do so."14

Part II of this paper will discuss the legal background and courts' analysis of the Tiffany and Gucci cases. Part II will also look at the laws and legal opinions governing evidence disclosure abroad for use in United States litigation as well as Chinese laws on judicial assistance and banking privacy. Part III will discuss the problems with the current analysis as it is applied to non-party Chinese banks in these cases. The current analysis permits a pro-forum bias and places courts in the position of weighing the relative interests of the United States and foreign sovereigns. Part III will argue that the resolution in the Tiffany cases was the ideal result. Giving China a chance to comply with a Hague Evidence Convention request best serves the interests of both the United States and China while remaining sensitive to the interests of the parties involved in the suit.

\section{BACKGROUND}

\section{A. Methods of Foreign Discovery in United States Courts}

1. Federal Rules of Civil Procedure

The Federal Rules govern the discovery process in United States federal courts. Under Federal Rule 26, parties to the litigation, without the use of an intermediary, may "obtain discovery regarding any nonprivileged matter that is relevant to any party's claim or defense." 15 While the Federal Rules provide standards for gathering a number of different types of evidence, the cases involved in this analysis involve requests to produce documents served on non-parties. Federal Rule 45 governs the use of subpoenas to compel non-parties to a lawsuit to produce documents. ${ }^{16}$ A subpoena may command the person on whom it is served to "produce designated documents, electronically stored

14. Tiffany, 2012 U.S. Dist. LEXIS 72148, at *21.

15. FED. R. CIV. P. 26(b)(1).

16. FED. R. CIV. P. 45(a)(1)(A)(iii). 
information, or tangible things in that person's possession, custody, or control." 17 Additionally, courts may hold in contempt any person who fails to respond to a subpoena without adequate excuse. ${ }^{18}$ Parties can also move to compel disclosure under Federal Rule $37 .{ }^{19}$

\section{The Hague Convention on Taking Evidence Abroad in Civil or Commercial Matters}

The Hague Evidence Convention, concluded in $1970,{ }^{20}$ was intended to bridge the gap between common law and civil law jurisdictions, ${ }^{21}$ and "establish a system for obtaining evidence located abroad that would be 'tolerable' to the state executing the request and would produce evidence 'utilizable' in the requesting state." 22 One issue which causes particular contention is pretrial discovery, particularly the "aggressive" nature of American-style discovery. ${ }^{23}$ Common law jurisdictions, like the United States, use an adversary system to litigate cases, ${ }^{24}$ and parties to the lawsuit are responsible for collecting and presenting evidence to support their arguments. ${ }^{25}$ Because this system is based on the idea "that each party will have an equal ability to discover the evidence in his favor," parties use pretrial discovery to equalize their access to evidence. ${ }^{26}$ This is in stark contrast to civil law jurisdictions, in which parties are only responsible for their own cases and are not obligated to produce adverse information for the other party. ${ }^{27}$ Additionally, the judge in civil law jurisdictions plays a primary role in bringing forth relevant evidence. ${ }^{28}$

17. Id.

18. FED. R. CIV. P. 45(g).

19. FED. R. CIV. P. 37(a)(1).

20. Convention on the Taking of Evidence Abroad in Civil or Commercial Matters, July 27, 1970, 23 U.S.T. 2555 [hereinafter Hague Evidence Convention].

21. James A.R. Nafziger, Another Look at the Hague Evidence Convention After Aerospatiale, 38 TEX. INT'L L.J. 103, 103-04 (2003).

22. Societe Nationale Industrielle Aerospatiale v. U.S. Dist. Ct. for the S. Dist. of Iowa, 482 U.S. 522, 530 (1987) (quoting PHILIP W. AMRAM, EXPLANATORY REPORT ON THE CONVENTION ON Taking Evidence Abroad in Civil or Commercial Matters, S. Exec. Doc. A 92-2, at 11 (1972)).

23. Geoffrey C. Hazard, Jr., Discovery and the Role of the Judge in Civil Law Jurisdictions, 73 Notre Dame L. Rev. 1017, 1017 (1998); Bernard H. Oxman, The Choice Between Direct Discovery and Other Means of Obtaining Evidence Abroad: The Impact of the Hague Evidence Convention, 37 U. MiAMI L. REV. 733, 769 (1983).

24. Hazard, supra note 23, at 1019.

25. KuO-Chang HuANG, InTROdUCing Discovery INTO CiviL LAW 7 (2003).

26. Id.

27. Id. at $26-27$.

28. Hazard, supra note 23, at 1019. 
Thus, pretrial discovery, as used in the American system, is often seen as an affront to the sovereignty and operation of courts in civil law jurisdictions. $^{29}$

In order to address these differences, the Hague Evidence Convention provides three methods by which signatories may conduct evidence disclosure in foreign states: (1) letters of request, (2) use of a diplomatic or consular agent, or (3) use of a private commissioner. Chapter I of the Hague Evidence Convention covers evidence disclosures through letters of request. ${ }^{30}$ A judicial authority of a state that has acceded to the treaty (a contracting state) may use a letter of request to obtain evidence. ${ }^{31}$ Under Article 2, each contracting state designates a central authority. ${ }^{32}$ This authority is responsible for receiving letters of request from judicial authorities in other contracting states and transferring those letters to the relevant authority. ${ }^{33}$ However, "[1] etters of [r]equest... do not rely solely on comity for execution." ${ }^{34}$ A contracting state is obligated to execute a letter of request expeditiously, ${ }^{35}$ and the Hague Evidence Convention only provides two conditions under which a contracting state may refuse to execute a letter of request. ${ }^{36}$

29. Id. at 1017.

30. A letter of request (also known as a letter rogatory) is

[a] document issued by one court to a foreign court, requesting that the foreign court (1) take evidence from a specific person within the foreign jurisdiction or serve process on an individual or corporation within the foreign jurisdiction and (2) return the testimony or proof of service for use in a pending case.

BLACK's LAW DiCTIONARY 988 ( $9^{\text {th }}$ ed. 2009).

31. Hague Evidence Convention, supra note 20, at art. 1.

32. Id. at art. 2.

33. Id.

34. Ronald E. Myrick, Obtaining Evidence Abroad for Use in United States Litigation, 15 SUFFOLK TRANSNAT'L L.J. 1, 15 (1991).

35. Hague Evidence Convention, supra note 20, at art. 9.

36. Id. at art. 12.

The execution of a Letter of Request may be refused only to the extent that:

a) in the State of execution the execution of the Letter does not fall within the functions of the judiciary; or

b) the State addressed considers that its sovereignty or security would be prejudiced thereby.

Execution may not be refused solely on the ground that under its internal law the 
Chapter II of the Hague Evidence Convention covers the taking of evidence by diplomatic officers and consular agents, as well as commissioners. Diplomatic officers and consular agents may take evidence from nationals of the state they represent. ${ }^{37}$ They may also take evidence from nationals of their host state as long as a competent authority grants permission and they abide by the rules of that permission. $^{38}$ Persons appointed as commissioners may take evidence abroad without compulsion and with the permission of a competent authority, granted they follow the conditions of the permission. ${ }^{39}$ In addition to these methods of taking evidence, Article 23 of the Convention allows a contracting state to "declare that it will not execute Letters of Request issued for the purpose of obtaining pre-trial discovery documents as known in Common Law countries." 40

China acceded to the Hague Evidence Convention in 1997 and designated the Ministry of Justice (MOJ) as its central authority. ${ }^{41}$ While China is a signatory to the Hague Evidence Convention, it included a number of reservations as part of its accession to the treaty. ${ }^{42}$ First, Chapter II is not applicable with the exception of Article 15, which authorizes diplomatic officers or consular agents to take evidence from nationals of the state they represent. ${ }^{43}$ Second, in accordance with Article 23, China has declared it will only execute such requests for pretrial discovery when the documents are clearly enumerated in the letters of request and those documents have a "direct and close

\footnotetext{
State of execution claims exclusive jurisdiction over the subject-matter of the action or that its internal law would not admit a right of action on it.

37. Id. at art. 15 .

38. Id. at art. 16

39. Id. at art. 17 .

40. Id. at art. 23

41. Status Table, HagUe CONFERENCE ON PrIVATE INT'L LAw, http://www.hcch.net/ index_en.php?act=conventions.status\&cid=82 (last visited October 27, 2013); Authorities, HAGUE CONFERENCE ON PRIVATE INT'L LAW, http://www.hcch.net/index_en.php?act=authorities.details \&aid $=490$ (last visited October 27, 2013).

42. Upon accepting or acceding to a treaty, a state may include reservations as to certain terms, in effect rejecting that term of the treaty. MARK JANIS, INTERNATIONAL LAW 24 (6th ed. 2012). Other parties to the treaty may need to actually accept the reservation in order to make the modification legally binding. Id. However, if the treaty has explicitly allowed for certain reservations, acceptance may be assumed. Id. In Article 23, the Hague Evidence Convention explicitly allows for states to make a reservation not to execute requests for pretrial discovery. Hague Evidence Convention, supra note 20, at art. 23.

43. Declarations Notifications Reservations, Hague Evidence Convention, supra note 20, available at http://www.hcch.net/index_en.php?act=status.comment\&csid=493\&disp=resdn (last visited October 27, 2013).
} 
connection with the subject matter of the litigation." 44 As a member of the Hague Evidence Convention, the MOJ is obligated to execute requests that comply with its reservation and to do so in an expedient manner.

3. Societe Nationale Industrielle Aerospatiale v. United States District Court for the Southern District of Iowa

The seminal Supreme Court case regarding foreign discovery under the Hague Evidence Convention is Societe Nationale Industrielle Aerospatiale v. United States District Court for the Southern District of Iowa. ${ }^{45}$ In Aerospatiale, two American citizens brought suit against two French corporations in the United States District Court for the Southern District of Iowa for negligence and breach of warranty. ${ }^{46}$ Following the American litigants' second set of discovery requests under the Federal Rules, the French parties filed a motion for a protective order, arguing that the Hague Evidence Convention was the "exclusive and mandatory procedure[] for obtaining documents and information located within the territory of a foreign signatory." 47 In a five-to-four decision, the Supreme Court held the Hague Evidence Convention was neither an exclusive nor a mandatory means of obtaining discovery abroad; rather, the Convention provided another option, but this option did not displace the Federal Rules when conducting discovery in United States litigation. ${ }^{48}$ The Court declined to adopt a rule of first resort because use of the Hague Evidence Convention would be "unduly time consuming and expensive" ${ }^{49}$ in certain circumstances, and was less certain to produce the requested evidence than the Federal Rules. ${ }^{50}$

In place of a bright-line rule, the Court provided a five-factor comity analysis taken from the Restatement of Foreign Relations Law of the United States (Revised) Section 437(1)(c), which United States courts use in determining whether to conduct foreign discovery under the

\footnotetext{
44. Id.

45. 482 U.S. 522 (1987).

46. Id. at $524-25$.

47. Id. at $525-29$.

48. Id. at $538-40$.

49. Id. at 542. The Court did not provide any evidence to support either of these contentions. Id. at 561 (Blackmun, J., concurring in part, dissenting in part).

50. Id. at 542 (noting that in cases in which the Hague Evidence Convention would produce more evidence more quickly, the first-use strategy would prevail).
} 
Federal Rules or the Hague Evidence Convention. ${ }^{51}$ The analysis weighs five factors:

(1) the importance to the... litigation of the documents or other information requested;

(2) the degree of specificity of the request;

(3) whether the information originated in the United States;

(4) the availability of alternative means of securing the information; and

(5) the extent to which noncompliance with the request would undermine important interests of the United States, or compliance with the request would undermine important interests of the state where the information is located. ${ }^{52}$

In his dissent, Justice Blackmun argued that in most cases, courts should resort to the Hague Evidence Convention because "the Convention provides effective discovery procedures that largely eliminate the conflicts between United States and foreign law on evidence gathering." 53 An individualized analysis of a case would only be necessary when use of the Convention would be unhelpful or futile. ${ }^{54}$ While Justice Blackmun agreed the Convention was not meant to be mandatory, he also asserted it was more than merely advisory. ${ }^{55}$ The Hague Evidence Convention had been crafted to further important United States' interests by creating greater access to discovery in civil law countries and maintaining a "climate of cooperation and goodwill necessary to the functioning of the international legal and commercial systems." ${ }^{, 56}$ Justice Blackmun also warned that courts are ill-suited to balance the interests of foreign states against those of the United States. ${ }^{57}$ This would increase the likelihood of a "pro-forum bias" in comity analyses with United States courts often resorting to local rules. ${ }^{58}$

\footnotetext{
51. Id. at $544 \mathrm{n} .28$.

52. Id. (citing Restatement of Foreign Relations LAW OF THE UNited StATES (REVISED) $\S 437(1)(c)$ (Tentative Draft No. 7, 1986)).

53. Id. at 548-49 (Blackmun, J., concurring in part, dissenting in part).

54. Id. at 549 .

55. $I d$.

56. Id. at 550 .

57. Id. at 552 .

58. Id. at 553 .
} 


\section{B. Applicable Chinese Laws}

\section{Judicial Assistance}

Evidence disclosure conducted by foreign states in China is governed domestically by the Civil Procedure Law of the People's Republic of China (Civil Procedure Law). ${ }^{59}$ Article 277 provides that "[j]udicial assistance shall be requested and provided through the channels prescribed in an international treaty concluded or acceded to by the People's Republic of China; or in the absence of such a treaty, shall be requested and provided through diplomatic channels." 60 Absent these circumstances or permission from an authorized agency of the People's Republic of China (PRC), no foreign authority or individual may serve process, conduct an investigation, or collect evidence within the territory of the PRC. ${ }^{61}$

In addition to the Civil Procedure Law, the Supreme People's Court also promulgated the Provisions of the Supreme People's Court on Handling Requests for Judicial Assistance in Service of Judicial Documents, Investigation and Taking of Evidence in Civil and Commercial Cases in Accordance with International Conventions and Bilateral Treaties on Judicial Assistance (Provisions on Judicial Assistance). ${ }^{62}$ Under this law, requests by China for judicial assistance in foreign countries shall be carried out pursuant to the Hague Evidence Convention. ${ }^{63}$ Requests for judicial assistance in China made by foreign countries shall be conducted according to the Civil Procedure Law and any relevant judicial interpretations. ${ }^{64}$

59. Zhonghua Renmin Gonghe Guo Minshi Susong Fa (2012 Xiuzheng) (中华人民共和国民 事诉公法(2012 修正)) [Civil Procedure Law of the People's Republic of China (2012 Amendment)] (promulgated by the Standing Comm. Nat'l People's Cong., Aug. 31, 2012, effective Apr. 9, 1991) (Lawinfochina) (China).

60. Id. at art. 277.

61. Id.

62. Zuigao Renmin Fayuan Guanyü Yijü Guoji Gongyue He Shuangbian Sifa Xiezhu Tiaoyue Banli Minshangshi Anjian Sifa Wenshu Songda He Diaocha Qüzheng Sifa Xiezhu Qingqiude Guiding (最高人民法院关于依据国际公约和双边司法协助条约办理民商事案件司法文书送达 和调查取证司法协助请求的规定) [Provisions of the Supreme People's Court on Handling Requests for Judicial Assistance in Service of Judicial Documents, Investigation and Taking of Evidence in Civil and Commercial Cases in Accordance with International Conventions and Bilateral Treaties on Judicial Assistance] (promulgated by Sup. People's Ct., Apr. 7, 2013, effective May 2, 2013) (Lawinfochina) (China).

63. Id. at art. 1 .

64. Id. at art. 3 . 


\section{Banking Laws}

China's banking privacy regime is created by a number of laws that prohibit the disclosure of information regarding bank accounts and provide penalties for any entity that violates such laws. One of the key laws relating to Chinese banks is the Law of the People's Republic of China on Commercial Banks (Commercial Banks Law). ${ }^{65}$ Article 6 of the Commercial Banks Law requires commercial banks to "protect the legal rights and interests of . . . depositors against ... encroachment [by] any entity or individual." ${ }^{\circ 6}$ Under Article 73, a commercial bank that illegally discloses information about, freezes, or debits a deposit account is subject to a number of penalties depending on the damage caused. ${ }^{67}$ In cases where there have been no illegal gains, the "banking regulatory organ of the State Council” shall impose a fine of no less than $¥ 50,000$ renminbi to no more than $¥ 500,000$ renminbi. ${ }^{68}$

The Notice of the People's Bank of China on Promulgating the Provisions on the Administration of Financial Institutions' Assistance in the Inquiry, Freeze or Deduction of Deposits (Financial Institutions' Assistance Provisions) provides the conditions under which certain financial institutions-including wholly state-owned commercial banks - can disclose depositor information, freeze accounts, or debit funds from accounts. ${ }^{69}$ A notice of a request for disclosure must be served by an officer of a competent organ, and financial organs are prohibited from accepting notices served by anyone other than an officer of a competent organ. ${ }^{70}$ The regulation provides a list of authorities who are competent to request such information. ${ }^{71}$ According to the

65. Zhonghua Renmin Gonghe Guo Shangye Yinhang Fa (2003 Xiuzheng) (中华人民共和国 商业银行法(2003 修正)) [Law of the People's Republic of China on Commercial Banks] (promulgated by the Standing Comm. Nat'1 People's Cong., Dec. 27, 2003, effective June 1, 1995) (Lawinfochina) (China).

66. Id. at art. 6.

67. Id. at art. 73.

68. $I d$.

69. Zhonghua Renmin Yinhang Guanyü Fabu "Jinrong Jigou Xiezhu Chaxün, Dongjie, Kouhua Gongzuo Guanli Guiding” de Tongzhi (中国人民银行关于发布《金融机构协助查询、冻 结、扣划工作管理规定》的通知) [Notice of the People's Bank of China on Promulgating the Provisions on the Administration of Financial Institutions' Assistance in the Inquiry, Freeze or Deduction of Deposits] (promulgated by the People's Bank of China, Jan. 15, 2002, effective Feb. 1, 2002) (Lawinfochina) (China).

70. Id. at art. 21.

71. Id. at art. 24 . 
regulation, the Supreme People's Court is competent to make such requests but foreign courts are not. ${ }^{72}$

The Criminal Law of the People's Republic of China also provides penalties for entities that disclose private banking information. ${ }^{73}$ Under Article 253(A), a financial entity that illegally discloses private information on citizens in the course of its duties is subject to punishment if the circumstances are serious. ${ }^{74}$ These penalties include imprisonment or criminal detention of no more than three years, fines, or both. $^{75}$

\section{Recent Cases Involving Discovery Requests Directed at Non-Party Chinese Banks}

The Southern District of New York has recently decided a number of cases involving trademark suits brought by American corporations against Chinese counterfeiters. In each case, the plaintiffs attempted to compel discovery of bank records from non-party Chinese banks under the Federal Rules, and the banks asked the court to instead use the Hague Evidence Convention due to conflicts between the Federal Rules and internal Chinese law. Following the ruling in Aerospatiale, the judges applied a five-factor comity analysis, plus two additional factors used in the Southern District, ${ }^{76}$ to determine whether to conduct discovery under the Federal Rules or the Hague Evidence Convention. Despite almost identical circumstances, the courts in these cases reached different conclusions on how to conduct the requested discovery.

\section{Tiffany (NJ) LLC v. Qi Andrew}

In Tiffany (NJ) LLC v. Qi Andrew (hereinafter Tiffany I), luxury goods manufacturer Tiffany brought claims against several Chinese defendants who were selling counterfeit Tiffany goods on websites

\footnotetext{
72. Id.

73. Zhonghua Renmin Gonghe Guo Xingfa Xiuzheng An (Qi) (中华人民共和国刑法修正案 (七)) [Amendment (VII) to the Criminal Law of the People's Republic of China] (promulgated by the Standing Comm. Nat'l People's Cong., Feb. 28, 2009, effective Feb. 28, 2009) (Lawinfochina) (China).

74. Id. at art. 254 .

75. Id.

76. Tiffany (NJ) LLC v. Qi Andrew, 276 F.R.D. 143, 151 (S.D.N.Y. 2011) (citing Gucci Am., Inc. v. Curveal Fashion, No. 09 Civ. 8458, 2010 U.S. Dist. LEXIS 20834, at *6 (S.D.N.Y. March 8, 2010)).
} 
hosted in the United States. ${ }^{77}$ Tiffany served a subpoena pursuant to Federal Rule 45 on the New York branches of the Bank of China (BOCNY), the Industrial and Commercial Bank of China (ICBCNY), and China Merchants Bank (CMBNY) for records related to the defendants' accounts. ${ }^{78}$ All three banks searched their records held in the United States but were unable to find any documents matching the information provided by the plaintiffs. ${ }^{79}$ The banks also claimed that records kept outside of the United States were beyond their "custody[] or control," 80 and that producing such documents held in China would violate Chinese law. ${ }^{81}$ Both BOCNY and IBCNY did, however, offer to assist the plaintiffs in preparing a discovery request pursuant to the Hague Evidence Convention. ${ }^{82}$ The plaintiffs moved to compel production of the documents. ${ }^{83}$ In response, the banks opposed the motion, arguing they did not "have custody or control of documents located in China" and the "plaintiffs' motion should be denied in accordance with notions of comity." $" 84$

The court dismissed the banks' first argument finding the records held in China were within the New York branches' custody and control. ${ }^{85}$ Next, the court turned to the issues of comity raised by the banks. The banks contended that compliance with the subpoena would require violating several Chinese laws - specifically, China's banking privacy laws. ${ }^{86}$ Because of this conflict of laws, the court engaged in the five-factor comity analysis mentioned in Aerospatiale, along with two additional factors used in the Southern District, to determine whether the banks should be compelled to produce the documents under the Federal

77. Id. at 145 .

78. Id.

79. $I d$.

80. FED. R. CIV. P. 45(a)(1)(A)(iii).

81. Tiffany, 276 F.R.D. at 158.

82. Id. at 146 .

83. Id.

84. Id.

85. Id. at 147-50. Courts use a rebuttable presumption that "[a] corporation ... [has] custody and control of its own records ordinarily required in the course of business ...." Id. at 148. Since the subpoenas were served on the corporate entity of the banks (not just their individual branches), the banks were unable to show that the banks as a whole did not have control over records kept in China. Id. at 149 .

86. Id. at 150 . 
Rules or whether further evidence disclosure should be conducted under the Hague Evidence Convention. ${ }^{87}$

On the first and second factors of the comity analysis (importance of the documents to the litigation and the specificity of the request), the court found in favor of the plaintiffs - the information requested was important because it could reveal the identities of counterfeiters and other defendants, and the document request was sufficiently specific. ${ }^{88}$ The third factor (origin of information) weighed in favor of the banks because the Chinese bank records clearly originated outside the United States. ${ }^{89}$

While the first three factors of the analysis were relatively straightforward in this case, the analysis of the fourth and fifth factors proved more contentious. The fourth factor of the comity analysis required the court to determine if there was an alternative means to the Federal Rules of securing the information requested. ${ }^{90}$ In support of their argument, the plaintiffs cited language which had previously been posted on the United States Department of State website stating:

While it is possible to request compulsion of evidence in China pursuant to a letter rogatory or letter of request (Hague Evidence Convention), such requests have not been particularly successful in the past. Requests may take more than a year to execute. It is not unusual for no reply to be received or after a considerable time has elapsed, for Chinese authorities to request clarification from the American court with no indication that the request will eventually be executed. ${ }^{91}$

In response, the banks argued this language was not necessarily indicative of the current treatment of Hague Evidence Convention requests in China. First, they noted this language had since been removed from the website. ${ }^{92}$ While the State Department did not provide its reason for the removal, the banks claimed the removal suggested the State Department no longer regarded the information as accurate. ${ }^{93}$ In further support of their argument, the banks also cited statistics on the MOJ website reporting China had executed approximately fifty percent of the letters of request it had received in the past five years, with

\footnotetext{
87. Id. at 151 (citing In re Maxwell Commc'n Corp., 93 F.3d 1036, 1049 (2d Cir. 1996)).

88. Id. at $151-52$.

89. Id. at 152 .

90. Id. at 151 .

91. Id. at 153 .

92. $I d$.

93. Id.
} 
requests taking an average of six to twelve months to be executed. ${ }^{94}$ The MOJ had also executed thirty-seven requests in the first half of $2010 .^{95}$ CMBNY also noted, however, that because "the Chinese legal system has been developing rapidly over the last several years ... there [was] little precedent concerning Chinese handling of Hague Convention requests." $" 96$

Both the plaintiffs and the banks provided expert opinions in support of their positions. ${ }^{97}$ Many of the proffered opinions relied on either the language removed from the State Department website or the statistics provided by the MOJ. ${ }^{98}$ After review, the court concluded the experts were interpreting the same empirical evidence in different ways; thus, their opinions did not push the analysis in favor of either party. ${ }^{99}$ The court was ultimately unpersuaded by the plaintiffs' arguments that requests for evidence disclosure under the Hague Evidence Convention would be "futile" and found the fourth factor in favor of the banks. ${ }^{100}$

The fifth factor required the court to balance United States' interests involved in the case against foreign sovereign interests. ${ }^{101}$ The banks contended, "China has a significant interest in enforcing its banking privacy laws" because such laws are necessary to create confidence in China's relatively new banking system. ${ }^{102}$ The plaintiffs countered by arguing the "United States interest in fully and fairly adjudicating matters before its courts ... outweighs [a foreign country's interest] in protecting the confidentiality of its banking customers' records."103 The plaintiffs also argued that the United States has a significant interest in enforcing its trademark laws. ${ }^{104}$ The court ultimately found in favor of the banks, noting that Chinese banking laws "have few exceptions and appear to

$$
\begin{array}{ll}
\text { 94. } & I d . \\
95 . & I d . \\
96 . & I d . \text { at } 156 . \\
97 . & I d . \text { at } 154-55 . \\
98 . & I d . \\
\text { 99. } & I d . \text { at } 155 . \\
\text { 100. } & I d . \text { at } 156 . \\
\text { 101. } & I d . \text { at } 151 . \\
\text { 102. } & I d . \text { at } 156 . \\
\text { 103. } & I d . \text { at } 157 . \\
104 . & I d .
\end{array}
$$


provide harsh consequences for violations."105 The court also found the banks' status as non-parties swayed this factor in their favor. ${ }^{106}$

The court continued with the two additional factors used by the Southern District in a comity analysis: the nature of the hardship (sixth factor) and the good faith of the party resisting discovery (seventh factor). To demonstrate hardship, the banks needed to show there was a possibility of civil punishment, criminal punishment, or both if they were forced to comply with the subpoena, and that the possibility was more than speculative. ${ }^{107}$ The banks cited to two cases in which BOC had been punished for unintentionally disclosing information protected by banking privacy laws. ${ }^{108}$ The plaintiffs argued these cases were not identical to the present case, but failed to provide any evidence of a Chinese bank complying with a United States court for disclosure of evidence without incurring consequences. ${ }^{109}$ The court found the banks' argument more persuasive on this factor. ${ }^{110}$

Since there was no evidence in the record of the banks acting in bad faith, the court also found the seventh and final factor (use of good faith) in favor of the banks. ${ }^{111}$ Finding that the comity analysis on the whole weighed in favor of the banks, the court directed the plaintiffs to request evidence disclosure for the Chinese bank records through the Hague Evidence Convention, and if such request proved futile, plaintiffs would then be able to "renew their application to enforce their subpoenas."

\section{Gucci America, Inc. v. Weixing Li}

One month after Tiffany I, Gucci America, Inc. also attempted to compel evidence disclosure from BOCNY. Gucci served BOCNY with a subpoena on July 13, 2010. ${ }^{113}$ On July 26, 2010, BOCNY filed objections claiming, as in Tiffany I, that it did not have custody or control of records in China, compliance with the subpoena would violate

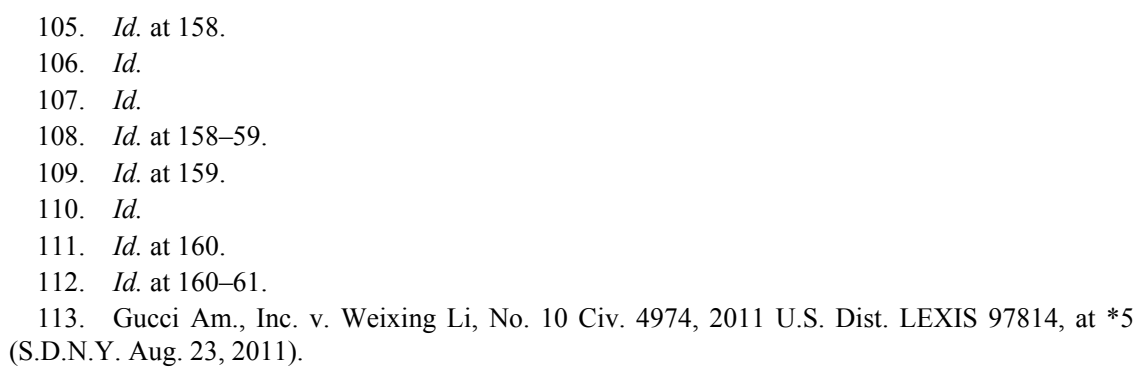


Chinese bank secrecy laws, and the request should be made under the Hague Evidence Convention. ${ }^{114}$ BOC eventually produced documents possessed by its New York branch but refused to produce any documents possessed by any of its Chinese branches. ${ }^{115}$

In this case, the court also conducted the seven-factor comity analysis to determine whether BOC would be compelled to produce evidence under the Federal Rules. For reasons similar to those used in Tiffany I, the court found the first factor (importance of documents to litigation $)^{116}$ and second factor (specificity of the request) ${ }^{117}$ in favor of the plaintiffs, and the third factor (whether information originated in the United States) ${ }^{118}$ and seventh factor (good faith) ${ }^{119}$ in favor of BOC. The court's analysis of factors four, five, and six differed from Tiffany I and ultimately led to the opposite outcome.

In analyzing whether there was an alternative means for securing the information sought (fourth factor), the Gucci court rejected the Tiffany I court's standard that the plaintiffs must demonstrate that the Hague Evidence Convention would be "futile." 120 Instead, the court, citing language from Aerospatiale, required that BOC show a Hague Evidence Convention request would be "effective." 121 In arguing its case, BOC again pointed to the removal of the language quoted in Tiffany I from the State Department's website, and similar statistics on the execution of Hague Evidence Convention requests in China. ${ }^{122}$ The court, however, reviewed prior jurisprudence on requests under the Hague Evidence Convention in the Southern District of New York and concluded the general opinion was that such requests were prone to indefinite delays and uncertain to ever be executed. ${ }^{123}$ In addition, while the expert opinions provided by the plaintiffs cited the language from the State Department website, the court found the opinions sufficiently relied on

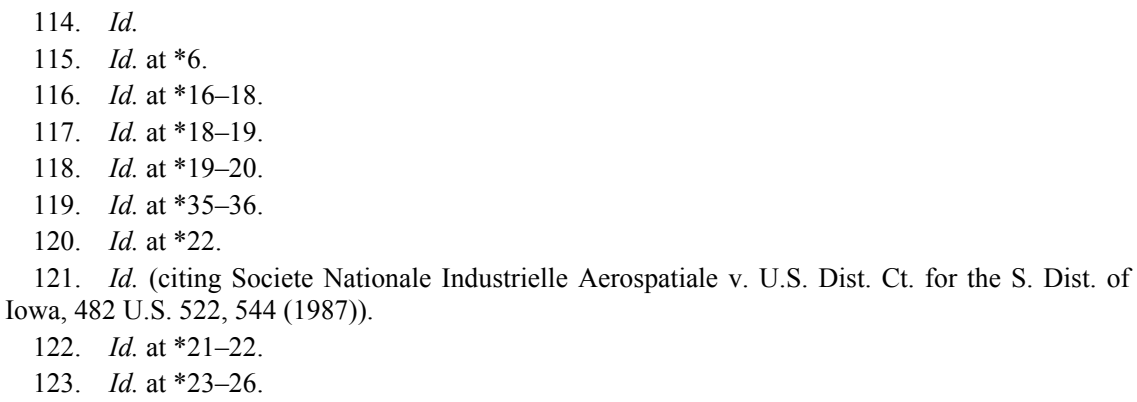


other sources of information to support their conclusions. ${ }^{124}$ Therefore, the court did not find the unexplained removal of the language from the State Department's website persuasive, and found the fourth factor in favor of the plaintiffs. ${ }^{125}$

In balancing the national interests of the United States and China (fifth factor), the Gucci court also differed from Tiffany I by finding the interests of enforcing United States law more significant. ${ }^{126}$ In reaching this conclusion, the court noted that Chinese banking secrecy laws could be waived by a number of entities and thus resembled more of an "individual privilege" for customers rather than "a national policy entitled to substantial deference." "27 According to the court, the Chinese government's failure to object to disclosure in the case only highlighted the lack of a significant national interest. ${ }^{128}$ The United States' interest in enforcing its intellectual property laws thus outweighed any nominal interest China might have in its banking secrecy laws. ${ }^{129}$

The final factor in which the Gucci court disagreed with Tiffany I was hardship of compliance (sixth factor). BOC again cited two cases in which it had been punished for unintentionally disclosing client information. ${ }^{130}$ The court found the cases to be inapposite as they did not involve requests for evidence disclosure by a foreign court. ${ }^{131}$ In addition, BOC was unable to cite to any instance of a Chinese bank being punished for complying with a foreign request for evidence disclosure. ${ }^{132}$ Because there was no definitive evidence that BOC would be punished for complying with the subpoena, the Gucci court found the threat of sanction too speculative and found for the plaintiffs. ${ }^{133}$

\section{Tiffany (NJ) LLC v. Forbse}

In a third case decided almost a year after Gucci, Tiffany (NJ) LLC v. Forbse (hereinafter Tiffany II), the court again applied a comity analysis

\footnotetext{
124. Id. at $* 26-27$.

125. Id. at $* 27$.

126. Id. at $* 27-31$.

127. Id. at $* 29$.

128. Id. at $* 29-30$.

129. Id. at *31.

130. Id. at $* 32-33$.

131. Id. at $* 33-34$.

132. Id.

133. Id. at *35-36.
} 
to determine if three Chinese banks- $\mathrm{BOC}, \mathrm{CMB}$, and ICBC-would be compelled to disclose evidence under the Federal Rules. ${ }^{134}$ In analyzing the fourth factor (availability of alternative means), the court noted that the Supreme Court in Aerospatiale had advised courts to "demonstrate due respect for any special problem confronted by the foreign litigant on account of its nationality or the location of its operations, and for any sovereign interest expressed by a foreign state." ${ }^{135}$ In arguing their positions, both sides again cited the statistics from the MOJ website, and the plaintiffs pointed out that over six months had passed since the Tiffany I court had transmitted a Hague Evidence Convention request, and China had yet to respond. ${ }^{136}$

The banks, however, were also able to submit a letter from two Chinese financial regulatory bodies, the People's Bank of China (PBOC), and the Chinese Banking Regulatory Commission (CBRC), addressed to four judges in the Southern District of New York. ${ }^{137}$ The letter stated that the banks are prohibited by Chinese law from disclosing customer account information in response to a United States court order. ${ }^{138}$ Therefore, they asked the judges to require parties to request such information through the Hague Evidence Convention procedures. ${ }^{139}$ The letter also expressed that the PBOC and CBRC "are committed to actively coordinating with the PRC Ministry of Justice and judicial organs in the PRC to ensure that they satisfy that requests for seeking evidence under the Hague Convention within a reasonable time period and by following the procedures thereunder." 140 Because the Chinese government had expressed willingness to cooperate and the statistics provided by both sides remained speculative, the court decided the best option was to "forebear from assuming that the Hague Convention is not a viable option until Chinese authorities have had a meaningful opportunity to comply with similar requests but have failed to do so."141

134. Tiffany (NJ) LLC v. Forbse, No. 11 Civ. 4976, 2012 U.S. Dist. LEXIS 72148, at*12-13 (S.D.N.Y. May 23, 2012).

135. Id. at *18 (citing Societe Nationale Industrielle Aerospatiale v. U.S. Dist. Ct. for the S. Dist. of Iowa, 482 U.S. 522, 546 (1987)).

136. Id. at *19-21.

137. Id. at *18. The letter was addressed to Judges Sullivan, Pauley, Pitman, and Batts, who all had similar cases on their dockets. See id. at *18 n.7.

138. Id. at *18.

139. Id. at *18-19.

140. Id. at $* 19$.

141. Id. at $* 20-21$. 
For the fifth factor (balancing national interests), the court found the United States' interest in enforcing its intellectual property laws in balance with Chinese interests in upholding its bank secrecy laws. ${ }^{142}$ It also agreed with the Gucci court and found the possibility of sanctions (sixth factor-hardship) to be too speculative in this case, specifically noting that the large ownership interest of the Chinese government in each of the banks would be a disincentive to any governmental regulatory actions. ${ }^{143}$ It ultimately ordered discovery under the Hague Evidence Convention for $\mathrm{CMB}$ and ICBC, but ordered discovery under the Federal Rules for BOC because the bank had acted in bad faith. ${ }^{144}$

\section{ANALYSIS}

The comity analysis as applied to non-party Chinese banks in these cases reveals a number of problems, particularly in the Gucci case. The cases since Aerospatiale fall into a general trend in which courts demonstrate a pro-forum bias, often choosing to compel evidence disclosure under the Federal Rules even when doing so would violate foreign law. ${ }^{145}$ The courts were also placed in a position to weigh United States and Chinese sovereign interests. ${ }^{146}$ Despite these issues, the outcome in the Tiffany cases provided the most even-handed approach to evidence disclosure from China: providing the Chinese government a chance to comply with the Hague Evidence Convention before turning to the Federal Rules.

\section{A. Current Comity Analysis in the Wake of Aerospatiale}

The use of the seven-factor comity analysis resulted in two different outcomes in the above cases: giving China the chance to comply with the Hague Evidence Convention procedures before resorting to the Federal Rules in the Tiffany cases, and granting a motion to compel evidence disclosure under the Federal Rules in Gucci. ${ }^{147}$ The courts reached these disparate results despite having similar or identical evidentiary

\footnotetext{
142. Id. at $* 21-25$.

143. Id. at $* 25-28$.

144. Id. at $* 30-31$.

145. See discussion infra Part III.A.1.

146. See discussion infra Part III.A.1.

147. See discussion infra Part III.A.1.
} 
records. ${ }^{148}$ The current method of comity analysis used in these cases has a number of flaws which allowed for such disparate outcomes. First, the current method of analysis allows courts to show an unfounded preference for United States' interests and the Federal Rules when weighing factors. ${ }^{149}$ This is particularly problematic when looking at cases that require a non-party to violate a foreign law in order to comply with a United States court order. Additionally, this method also allows for outcomes to be unduly influenced by attitudes toward the Chinese legal and banking systems. ${ }^{150}$

\section{Pro-Forum Bias and Criticism of Aerospatiale}

The minority in Aerospatiale predicted the new rule created by the case would be susceptible to a "pro-forum bias," and courts would often resort to more familiar local rules rather than those of the Hague Evidence Convention. ${ }^{151}$ Consistent with this prediction, a pro-forum bias has been the general trend of court decisions after Aerospatiale with many lower courts failing to give the laws and interests of foreign states the weight they may deserve. ${ }^{152}$ The issue has even been recognized by the American Bar Association (ABA), which issued a resolution in 2012 urging United States courts to show greater deference to data protection and privacy laws of foreign sovereigns in discovery requests in civil litigation. $^{153}$

In its resolution, the ABA noted that forcing parties to choose between violating foreign law or noncompliance with a United States discovery order "is inconsistent with promotion of rule of law, as it facilitates violation of law, either abroad or here." 154 The resolution specifically addresses the analysis of foreign banking privacy laws, finding that while some United States courts have recognized the validity of a foreign state's interest in enforcing banking privacy laws, those

\footnotetext{
148. See discussion supra Part II.D.1-2.

149. See discussion infra Part III.A.1.

150. See discussion infra Part III.A.1.

151. See supra text accompanying note 146 .

152. Patrick J. Borchers, The Incredible Shrinking Hague Evidence Convention, 38 TEX. INT'L L.J. 73, 82 (2003); Joseph P. Griffin \& Mark N. Bravin, Beyond Aerospatiale: A Commentary on Foreign Discovery Provisions of the Restatement (Third) and the Proposed Amendments to the Federal Rules of Civil Procedure, 25 INT'L LAW. 331, 337 (1991).

153. ABA Res. 103 (adopted by A.B.A. H.D., Feb. 6, 2012), http://www.americanbar.org/ content/dam/aba/administrative/house_of_delegates/resolutions/2012_hod_midyear_meeting_103.do $\mathrm{c}$ [hereinafter ABA Res. 103].

154. Id. at 3 .
} 
courts still tend to focus their analysis on whether the government has objected to the discovery order, and "any applicable exceptions to the foreign law and any ability of a banking customer to waive secrecy." This method of analysis frequently results in United States courts enforcing local discovery procedures over "challenges predicated on foreign banking statutes." 156

The Tiffany and Gucci cases follow in this trend. Rather than acknowledge that the existence of multiple Chinese regulations on the disclosure of deposit account information expresses the will of the Chinese government regarding bank privacy issues, all three cases looked to whether the Chinese government specifically objected to the particular request for evidence disclosure. ${ }^{157}$ In Tiffany II, the objection of two Chinese financial regulatory bodies helped push the analysis in favor of a request under the Hague Evidence Convention. ${ }^{158}$ In Gucci, the absence of any objection swayed the analysis in favor of the Federal Rules. $^{159}$

Interestingly, the PBOC and CBRC eventually issued a letter objecting to the discovery requests at issue in Gucci. ${ }^{160}$ The regulatory organs stated that they had issued a "severe warning" to BOC and were investigating $\mathrm{BOC}$ to determine the severity of the violation and the appropriate sanctions. ${ }^{161}$ While the court did not admit this letter as evidence in a later proceeding, it noted that even if evidence of the warning and investigation were admitted, it would not change the outcome of the analysis. ${ }^{162}$ Even though BOC had been warned and was under investigation, the PBOC and CBRC had not yet imposed sanctions or determined that BOC would definitely face sanctions, so the threat of punishment was still "unduly speculative."163 This method of reasoning appears to place banks (or other parties that are asked to violate foreign

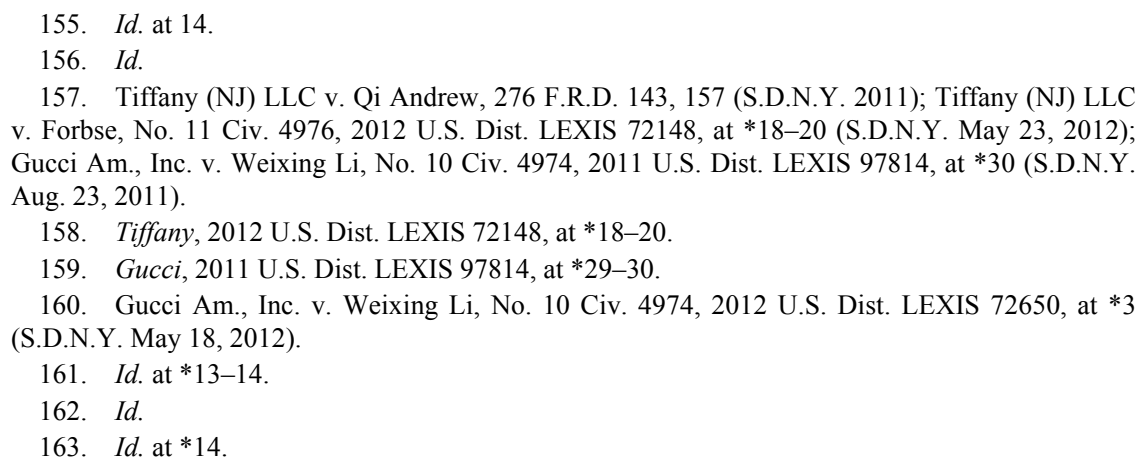


law to comply with the order of a United States court) in a precarious position - the only way they can prove they will be sanctioned is if they are actually sanctioned first. ${ }^{164}$

These cases also took note of any exceptions to the rule and the ability of governmental entities to waive secrecy, even coming to opposite conclusions despite analyzing the same law. The Tiffany I court concluded that Chinese banking privacy laws had few exceptions and harsh penalties, supporting the court's decision to proceed with discovery under the Hague Evidence Convention. ${ }^{165}$ The Gucci court found that the waivers and exceptions included in the banking privacy laws demonstrated that banking privacy was not of significant national interest to China, which helped push the court towards use of the Federal Rules. ${ }^{166}$ The Tiffany II court, while giving deference to the Chinese government's intervention, still "question[ed] the true extent of the Chinese interests at stake in [the] matter." "67 The court noted that the laws most certainly were not intended to protect counterfeiters, which was underscored by the number of Chinese governmental organs that may override banking secrecy provisions. ${ }^{168}$

The trend of pro-forum bias is only exacerbated when general attitudes or anxieties about the Chinese legal system and banking system are added to the mix. In their article Brand Name Replicas and Bank Secrecy: Exploring Attitudes and Anxieties Towards Chinese Banks in the Tiffany and Gucci Cases, attorneys Megan Chang and Terry Chang argue that rather than representing a disinterested analysis, the reasoning used in these cases reflects general anxieties and negative attitudes the United States has towards China. ${ }^{169}$

The authors first analyzed another banking privacy case, SEC v. Stanford International Bank Ltd., in which the court noted that Swiss banking laws served the "legitimate purpose of protecting commercial privacy." $" 170$ The court held that the Hague Evidence Convention struck

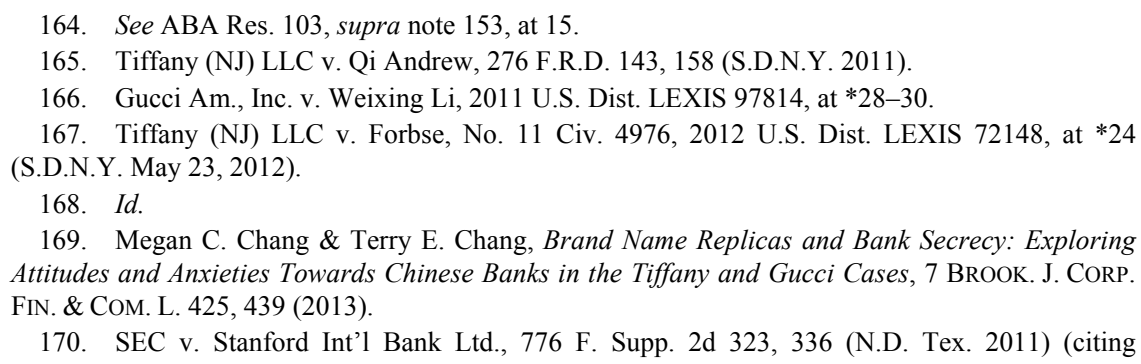

169. Megan C. Chang \& Terry E. Chang, Brand Name Replicas and Bank Secrecy: Exploring Attitudes and Anxieties Towards Chinese Banks in the Tiffany and Gucci Cases, 7 BROOK. J. CORP. Fin. \& COM. L. 425, 439 (2013).

170. SEC v. Stanford Int'l Bank Ltd., 776 F. Supp. 2d 323, 336 (N.D. Tex. 2011) (citing 
the right balance between the interests of both the United States and Switzerland because its "use will benefit U[nited] S[tates'] interests by providing the needed evidence, and protect Swiss interests by avoiding intrusions upon Swiss sovereignty." 171 The authors noted that similar language acknowledging the legitimacy of China's interest in its banking laws and the ideal balancing of interests under the Hague Evidence Convention was absent from the Tiffany and Gucci cases. ${ }^{172}$ This is in especially stark contrast to the language used in Gucci, which found that China's banking secrecy laws were a customer privilege rather than a significant national interest. ${ }^{173}$

In addition to this double standard, the cases involving Chinese banks also spent a great deal of time trying to assess whether China would execute requests under the Hague Evidence Convention-a question that was not even raised in the Swiss bank cases. ${ }^{174}$ The authors suggest this is because the court "found it unthinkable that the Swiss government would not comply with the Hague Convention." 175 Nor did any of the courts consider an intrusion on Chinese sovereignty as something that should necessarily be avoided. These comparisons are not meant to be an exhaustive study of the ways in which the Southern District of New York has analyzed foreign states' interests in their banking privacy laws. They can provide some light, though, as to the particular attitudes of the courts in the Tiffany and Gucci cases regarding China's sovereign interests.

These issues come on top of the serious criticism the Aerospatiale ruling has faced since being handed down. Two years after the ruling, the Hague Conference issued a Special Commission Report on the operation of the Hague Evidence Convention. ${ }^{176}$ The report acknowledged that contracting states disagreed as to whether the

Minpeco, S.A. v. ContiCommodity Serv’s, Inc., 116 F.R.D. 517, 524 (S.D.N.Y. 1987)).

171. Id. at 337 (quoting Brief of Government of Switzerland as Amicus Curiae in Support of Petitioners, Societe Nationale Industrielle Aerospatiale v. U.S. Dist. Ct. for S. Dist. of Iowa, 482 U.S. 522 (1987) (No. 85-1695), 1986 WL 727499, at *11).

172. Chang \& Chang, supra note 169 , at 438-39.

173. Gucci Am., Inc., v. Weixing Li, No. 10 Civ. 4974, 2011 U.S. Dist. LEXIS 97814, at*2931 (S.D.N.Y. Aug. 23, 2012).

174. Chang \& Chang, supra note 169 , at 439.

175. Id.

176. Special Commission Report on the Operation of the Hague Service Convention and the Hague Evidence Convention, April 20, 1989, 28 I.L.M. 1556. [hereinafter 1989 Special Commission Report]. 
Convention procedures were exclusive. ${ }^{177}$ The Commission noted, however, that given the object of the Convention, first priority should be given to the Convention procedures regardless of whether a state regarded such procedures as exclusive. ${ }^{178}$

In addition, most American commentary on the Aerospatiale ruling has also been highly critical both of the decision itself, and of its failure to provide clearer guidelines to lower courts. ${ }^{179}$ One scholar called the ruling a "disappointment" 180 for failing to adopt a rule of first resort to the Hague Evidence Convention in the interest of international comity. ${ }^{181}$ Another asserted the Aerospatiale ruling "create[ed] an undesirable and unworkable framework in which lower courts must make determinations about the appropriate use of the [Hague Convention]."182 A third stated that by failing to create an appropriate analytical framework, the decision "threaten[ed] to lead to conceptual chaos and may exacerbate rather than reduce current conflicts." 183 This is certainly not a comprehensive list of American criticism of the Aerospatiale ruling. These commentaries do, however, show a common concern: that the case was decided wrongly and, at the very least, has left lower courts with a confusing and unworkable standard by which to determine whether to carry out foreign discovery under the Federal Rules or the Hague Evidence Convention.

On the other hand, one particularly persuasive student note points out that the Aerospatiale decision should be credited with creating a rule of law in an area in which none existed before. ${ }^{184}$ While not specifically stated in the opinion, the Supreme Court may have had several important

\footnotetext{
177. Id. at 1564 .

178. Id.

179. Borchers, supra note 152, at 79; see also George A. Bermann, The Hague Evidence Convention in the Supreme Court: A Critique of the Aerospatiale Decision, 63 Tul. L. REV. 525 (1989); David J. Gerber, International Discovery After Aerospatiale: The Quest for an Analytical Framework, 82 A.J.I.L. 521, 530 (1988) (stating that the Court "failed to locate the principles it discussed in either a conceptual or a factual context"); Griffin \& Bravin, supra note 152, at 349; Patricia Anne Kuhn, Comment, Societe Nationale Industrielle Aerospatiale: The Supreme Court's Misguided Approach to the Hague Convention, 69 B. U. L. REv. 1011 (1989); Joseph Weis, The Federal Rules and the Hague Conventions: Concerns of Conformity and Comity, 50 U. PITT. L. REV. 903 (1989).

180. Bermann, supra note 179 , at 526 .

181. Id. at 536 .

182. Griffin \& Bravin, supra note 152 , at 349 .

183. Gerber, supra note 179 , at 522 .

184. J. Albert Garcia, Note, A Look Behind the Curtain, or Why the Hague Convention Had to Be Effectively Nullified, 23 TEX. INT'L L.J. 269, 288 (1988).
} 
American interests in mind in making its decision. ${ }^{185}$ First, the Court may have concluded that the United States entered into the Hague Evidence Convention with the purpose of creating an international system of discovery more like the American system. ${ }^{186}$ Second, United States courts had been conducting extraterritorial discovery under the Federal Rules for some time, and there is little to suggest that the United States government wanted to limit this practice. ${ }^{187}$ Last, and perhaps most significantly, the Court may have been attempting to protect the ability of United States courts to fairly adjudicate claims. ${ }^{188}$

While these interests are important considerations, they fail to support the Aerospatiale decision and the resulting framework as a whole. The Hague Evidence Convention is widely understood as an instrument designed to bridge the gap between common law (specifically American) discovery procedures and civil law evidence disclosure. ${ }^{189}$ Thus, by entering into the Convention, the United States was offering a compromise in the way its courts and litigants conducted discovery in signatory countries. Second, use of the Hague Evidence Convention does not necessarily preclude the fair adjudication of claims in United States courts. ${ }^{190}$ Additionally, while the adjudication of claims is of utmost importance to United States courts, discovery abroad implicates other United States and foreign interests which must be considered in reaching a solution.

\section{Special Considerations: Non-Party Status and Nature of Claim}

Another major issue in these cases is the significance of the Chinese banks' status as non-parties to the lawsuits. Based on the Hague Evidence Convention's legislative history, the authors appear to have

\footnotetext{
185. Id. at $280-83$.

186. Id. at 281 .

187. Id. at $282-83$.

188. Id. at 282 .

189. Nafziger, supra note 21, at 104.

190. In a 2003 study of American attorneys who had used the Hague Evidence Convention procedures, nineteen of thirty-seven respondents reported the use of the Convention did not delay litigation. Report on Survey of Experience of U.S. Lawyers with the Hague Evidence Convention Letter of Request Procedures, 2003 A.B.A. SEC. INT'L LAW \& PRACTICE 10-11. Fourteen of thirty respondents were able to obtain all the documents requested, while eighteen of thirty indicated the evidence obtained had an impact on the resolution of the case. Id. at 6,9 . While sixty percent of respondents felt their experience was not as satisfactory as expected, seventy-three percent reported they were "glad" they had used the Convention procedures and would use them again in similar circumstances. Id. at 6 .
} 
been primarily concerned with obtaining the testimony of witnesses outside the forum court's jurisdiction, although the final draft did not limit the convention's scope on this issue. ${ }^{191}$ Prior to the Supreme Court's ruling in Aerospatiale, several United States courts held that the Hague Evidence Convention would only apply in cases where production of evidence was requested from an entity who was neither a party to the lawsuit nor subject to the court's jurisdiction. ${ }^{192}$ The Aerospatiale opinion, however, held that the Hague Evidence Convention procedures would be available for evidence obtained from non-parties or litigants because the text of the Convention drew no distinction between the two. ${ }^{193}$

Despite the Court's ruling, some cases have again begun to recognize the significance of the status of the entity requesting use of the Hague Evidence Convention, at least when such requests are due to banking privacy laws or blocking statutes. ${ }^{194}$ Courts are more likely to compel discovery through the Federal Rules if the party is a litigant. ${ }^{195}$ This makes sense because a litigant requesting use of the Hague Evidence Convention is either a plaintiff seeking the benefits of United States law while attempting to block discovery, or a defendant who may have violated United States law. ${ }^{196}$ However, a non-party requesting the use of the Hague Evidence Convention does not raise these concerns.

When non-parties are ordered to produce evidence, it "raises both questions of jurisdictional power (whether the United States court has the authority to compel production pursuant to United States rules) and system concerns (in that this type of order would seem particularly offensive to the host state involved)." 197 Because many such cases involve a non-party under the control of a litigant (e.g., a foreign

191. Oxman, supra note 23 , at $757-58$.

192. Hannah L. Buxbaum, Assessing Sovereign Interests in Cross-Border Discovery Disputes: Lessons from Aerospatiale, 38 TEX. INT'L L.J. 87, 99 (2003).

193. Id. at 99 (citing Societe Nationale Industrielle Aerospatiale v. U.S. Dist. Ct. for the S. Dist. of Iowa, 482 U.S. 522, 524, 541, 546 (1987)).

194. Monica Hanna \& Michael A. Wiseman, Discovering Secrets: Trends in U.S. Courts' Deference to International Blocking Statutes and Banking Secrecy Laws, 130 BANKING L.J. 692, 696 (2013). A blocking statute is a law "enacted to [strictly] prohibit the production of specific documents or entire categories of documents of particular concern to the foreign sovereign." $I d$. at 692.

195. Id. at 696 .

196. Peninsula Asset Mgmt. (Cayman) Ltd. v. Hankook Tire Co., No. 5:04-CV-1153, 2005 U.S. Dist. LEXIS 27815, at *6-7 (S.D.N.Y. Nov. 14, 2005), aff'd, 476 F.3d 140 (2d Cir. 2007).

197. Buxbaum, supra note 192, at 99. 
subsidiary of a corporation located in the United States), courts may more readily resolve the issue in favor of the use of the Federal Rules on jurisdictional grounds. ${ }^{198}$ Cases involving a non-party not under the control of a litigant, however, will raise different system-based concerns. ${ }^{199}$ As one court noted, civil law nations regard discovery within their borders as a violation of their sovereignty because factgathering is the responsibility of judges in their legal system. ${ }^{200}$ These orders are "particularly offensive" in cases where the entity being ordered to produce evidence is a non-party to the suit. ${ }^{201}$ Here, courts are left to decide how best to balance the parties' as well as the sovereigns' interests, which can lead to disparate outcomes in similar cases. ${ }^{202}$ While recent cases involving non-parties have been inconsistent in their findings ${ }^{203}$ courts have developed a general rule that use of the Hague Evidence Convention is mandatory when ordering discovery from a nonparty. ${ }^{204}$

Both Tiffany cases continued in this development by acknowledging the significance of the bank's status as a non-party. In Tiffany I, the court found "the Banks' status as non-parties ... attenuate[d] the United States interest in enforcing discovery obligations." ${ }^{205}$ Tiffany II also came to the same conclusion, citing Tiffany I. ${ }^{206}$ The Gucci court, on the other hand, failed to adequately take account of BOC's non-party status. $^{207}$ This likely made use of the Federal Rules more probable, because the court did not consider the sovereign interests involved in ordering discovery from a non-party located in a civil law jurisdiction.

\footnotetext{
198. See id. at $99-100$.

199. See id. (discussing the ruling in Orlich v. Helm Bros., 560 N.Y.S.2d 10, 14 (N.Y. App. Div. 1990)).

200. Orlich, 560 N.Y.S.2d at 15.

201. Id.

202. Hanna \& Wiseman, supra note 194 , at $698-99$.

203. Id. at 698

204. Nafziger, supra note 21, at 110 (citing PKFinans Int'l Corp. v. IBJ Schroder Leasing Corp., No. 93-5375, 1996 U.S. Dist. LEXIS 15183 (S.D.N.Y. Oct. 15, 1996); Intercontinental Credit Corp. v. Roth, 595 N.Y.S.2d 602 (N.Y. Sup. Ct. 1991); Orlich, 560 N.Y.S.2d 10); Griffin \& Bravin, supra note 152, at 349 n.76 (citing Rich v. KIS Cal., Inc., 121 F.R.D. 254, 257 (M.D.N.C. 1988); Orlich, 560 N.Y.S.2d at 15); Richard M. Dunn \& Raquel M. Gonzalez, The Thing about Non-U.S. Discovery for U.S. Litigation: It's Expensive and Complex, 67 DEF. Couns. J. 342, 347 (2000) (citing In re Honda Am. Motor Co., 168 F.R.D. 535, 540 (D. Md. 1996); Triple Crown Am., Inc. v. Biosynth AG, No. Civ.A. 96-7476, 1998 WL 227886 (E.D. Penn. April 30, 1998)).

205. Tiffany (NJ) LLC v. Qi Andrew, 276 F.R.D. 143, 157 (S.D.N.Y. 2011).

206. Tiffany (NJ) LLC v. Forbse, No. 11 Civ. 4976, 2012 U.S. Dist. LEXIS 72148, at *23 (S.D.N.Y. May 23, 2012).

207. Chang \& Chang, supra note 169 , at 439.
} 
In addition, by failing to recognize the banks' non-party status, the court "seemed to project some culpability on the bank." 208 While the issue of non-party status may not be dispositive, ${ }^{209}$ it weighs heavily in favor of use of the Hague Evidence Convention because of the lack of involvement of non-parties in the suit and the sovereign interests at stake.

Another key consideration is the nature of the claim being brought and the subsequent interests that claim implicates. Both the Tiffany and Gucci cases were civil suits targeted at counterfeiters violating American trademark law. Counterfeiting is undoubtedly a problem, both in the United States and worldwide. By some estimates, counterfeiting is worth $\$ 600$ billion a year, constituting five to seven percent of world trade. ${ }^{210}$ China holds a special position in the counterfeiting trade, standing as the world's top manufacturer and exporter of counterfeit goods. ${ }^{211}$ China has, in recent years, made great strides in its protection of intellectual property rights. Chinese law provides a number of domestic enforcement methods, including special courts that deal exclusively with intellectual property cases. ${ }^{212}$ In addition, China has become party to a number of international treaties that obligate it to bring itself in line with international standards on intellectual property rights. ${ }^{213}$ Regardless of these developments, though, counterfeiting in China continues to be a problem for American businesses.

Courts have routinely recognized the importance of enforcing American trademark laws in order to combat counterfeiting. The Tiffany and Gucci cases all acknowledged that the United States has a strong interest in protecting its trademark laws. ${ }^{214}$ Courts have even

208. Id. at 439 .

209. Hanna \& Wiseman, supra note 194, at 696.

210. Counterfeiting Intelligence Bureau, INT'L CHAMBER OF COM., http://www.iccwbo.org/ products-and-services/fighting-commercial-crime/counterfeiting-intelligence-bureau/ (last visited Oct. 27, 2014).

211. Intellectual Property Rights: Fiscal Year 2012 Seizure Statistics, U.S. CUSTOMS AND BORDER PROTECTION OFFICE OF INT'L TRADE, 15 http://www.cbp.gov/sites/default/files/ documents/FY2012\%20IPR\%20Seizure\%20Statistics_0.pdf (last visited Oct. 27, 2014).

212. Matthew A. Marcucci, Navigating Unfamiliar Terrain: Reconciling Conflicting Impressions of China's Intellectual Property Regime in an Effort to Aid Foreign Right Holders, 23 Fordham Intell. Prop. Media \& ENT. L.J. 1395, 1415-16 (2013) (citing Martin K. Dimitrov,

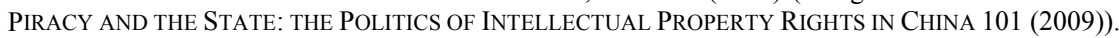

213. Kimberly Shane, Culture, Poverty, and Trademarks: An Overview of the Creation and Persistence of Chinese Counterfeiting and How to Combat It, 16 INTELL. Prop. L. BulL. 137, 14345 (2012).

214. Tiffany (NJ) LLC v. Qi Andrew, 276 F.R.D. 143, 157 (S.D.N.Y. 2011) (citations omitted); Tiffany (NJ) LLC v. Forbse, No. 11 Civ. 4976, 2012 U.S. Dist. LEXIS 72148, at *22 (S.D.N.Y. May 
acknowledged the enforcement of trademark laws as a public interest issue because of the harm done to consumers by counterfeit goods. ${ }^{215}$ Despite this, the interest in enforcing intellectual property rights does not invoke the same public interests as other types of cases. For one, trademark cases generally involve private parties rather than the United States government. ${ }^{216}$ Second, the interest in protecting trademark laws is not as compelling as other interests, which implicate public safety concerns, such as terrorism. ${ }^{217}$

A recent case involving BOC, Wultz v. Bank of China, addressed the issue of compelling discovery in order to combat terrorism. ${ }^{218}$ In Wultz, family members of a victim of a terrorist bombing brought suit against BOC for its alleged involvement in the financing of terrorism. ${ }^{219}$ As in the Tiffany and Gucci cases, BOC requested the use of the Hague Evidence Convention for discovery in China. ${ }^{220}$ In balancing the sovereign interests of the United States and China, the Southern District of New York found that when the fight against terrorism is combined with the need of United States courts to fully and fairly adjudicate cases, the "U.S. interest is elevated to nearly its highest point, and diminishes any competing interests of the foreign state." 221 The court ultimately ordered discovery under the Federal Rules. ${ }^{222}$

The decision in Wultz is understandable given the threat to public safety and United States sovereignty that terrorism poses. Counterfeiting, on the other hand, may be a multi-billion dollar a year business, but it does not implicate the same public safety issues as

23, 2012) (citations omitted).

215. Hermes Int'l v. Lederer de Paris Fifth Ave., 219 F.3d 104, 107-08 (2d Cir. 2000) (citing United States v. Torkington, 812 F.2d 1347, 1353 n. 6 (11th Cir. 1987)).

216. See Tiffany, 2012 U.S. Dist. LEXIS 72148, at*22 ("Nevertheless, the interest of the United States is not as great in this context-in which the discovery request is initiated by a private, civil litigant - as it would be if the request were initiated by the U.S. government for purposes of an enforcement proceeding.") (citations omitted).

217. See Wultz v. Bank of China, 910 F. Supp. 2d 548, 559 (S.D.N.Y. 2012) (tort claim based on financing of terrorism) ("Even in [Tiffany II] where the U.S. interest was not as great as it is here-because it was limited to the defense of intellectual property rights and protecting consumers from counterfeit products - the court concluded that those interests outweighed the Chinese interests.") (citations omitted).

218. Id.

219. Id. at 550 .

220. Id. at 551

221. Id. at 559 (quoting Strauss v. Credit Lyonnais, S.A., 249 F.R.D. 429, 443-44 (S.D.N.Y. 2012)).

222. Id. at 560 . 
terrorism. Thus, while cases based on terrorism may easily outweigh any interest of a foreign sovereign, counterfeiting cases do not carry the same weight.

\section{B. Tiffany I and II: The Best Approach to Ordering Discovery}

Tiffany $I$ and $I I$ came to the most workable conclusion when dealing with evidence disclosure in China: allowing China a chance to execute a letter of request through the Hague Evidence Convention before resorting to the Federal Rules. This holding adequately takes into account China's sovereign interests without being overly deferential to a legal system that has less transparency than many modern nation-states. The holding in Tiffany $I$ and $I I$ also acknowledges China's explicit commitment to complying with the Hague Evidence Convention and provides a better response to inconclusive evidence on China's history of executing Hague Evidence Convention requests. The ruling adequately accounts for the banks' status as non-parties and the nature of the suit being brought. It also serves the long-term interests of the United States by working to improve the often-tense relations between the United States and China. Thus, the approach used in the Tiffany cases would serve the interests of both the United States and China while still providing viable means of evidence disclosure for litigants.

1. China's Sovereign Interests and Commitment to the Hague Evidence Convention

In the Tiffany and Gucci cases, the courts addressed China's sovereign interest in its banking privacy laws. ${ }^{223}$ A primary goal of China's banking privacy laws is to encourage the development of the Chinese banking and financial system. ${ }^{224}$ According to Article 1 of the Commercial Bank Law, the law's purpose is to "protect[] the legal rights and interests of commercial banks, depositors and other clients... safeguard[] the financial order and promot[e] the development of the socialist market economy." 225 In his expert testimony in Tiffany I,

223. Tiffany (NJ) LLC v. Forbse , 276 F.R.D. 143, 157 (S.D.N.Y. 2011); Tiffany (NJ) LLC v. Forbse, No. 11 Civ. 4976, 2012 U.S. Dist. LEXIS 72148, at*18 (S.D.N.Y. May 23, 2012); Gucci Am., Inc. v. Weixing Li, No. 10 Civ. 4974, 2011 U.S. Dist. LEXIS 97814, at *27-30 (S.D.N.Y. Aug. 23, 2011).

224. See Tiffany, 276 F.R.D. at 160 (recognizing China's interest in "encouraging use of, and confidence in, its relatively new banking system").

225. Zhonghua Renmin Gonghe Guo Shangye Yinhang Fa (2003 Xiuzheng) (中华人民共和国 商业银行法(2003 修正)) [Law of the People's Republic of China on Commercial Banks] 
Professor James Feinerman of Georgetown Law School also confirmed that China's banking privacy laws were created to instill "confidence in a relatively new banking system and to "[e]ncourag[e] its citizens who had historically been skeptical about the safety of their deposits in banksand their continued access to them-[to utilize Chinese banks by providing] the strongest possible assurances of confidentiality." 226 Having a "relatively new banking system" means China has had fewer chances to enforce its laws against violators, and the Chinese government has had fewer chances to express its national interest in lawsuits involving these laws. Yet, these are the exact factors courts analyze in determining the weight of a sovereign's interest and the hardship of compliance for a non-party compelled to disclose evidence.

The holding in the Tiffany cases also recognizes China's commitment to the Hague Evidence Convention and better conforms to China's decisions to integrate the Hague Evidence Convention into domestic law. By signing the Hague Evidence Convention, the Chinese government has already expressed its intention to abide by the rules therein. The Civil Procedure Law essentially makes the Hague Evidence Convention the mandatory procedure for foreign states collecting evidence within China. ${ }^{227}$ The Provisions on Judicial Assistance also explicitly state that the Hague Evidence Convention is the method by which China will conduct evidence disclosure in foreign countries. ${ }^{228}$ Specifically regarding litigation related to banking and finance, both the PBOC and the CBRC have expressed their willingness to assist in the

(promulgated by the Standing Comm. Nat'l People's Cong., Dec. 27, 2003, effective June 1, 1995) (Lawinfochina) (China).

226. Tiffany, 276 F.R.D. at 156.

227. Zhonghua Renmin Gonghe Guo Minshi Susong Fa (2012 Xiuzheng) (中华人民共和国民 事诉讼法(2012 修正)) [Civil Procedure Law of the People's Republic of China (2012 Amendment)](promulgated by the Standing Comm. Nat'l People's Cong., Aug. 31, 2012, effective Apr. 9, 1991) (Lawinfochina) (China); see Fang Shen, Are You Prepared for This Legal Maze?: How to Serve Legal Documents, Obtain Evidence, and Enforce Judgments in China, 72 UMKC L. REv. 215, 229 (2003) ("Chapter 29, Article 236 of the Civil Procedure Law of the PRC provides that 'in requesting or offering judicial assistance, the procedures spelled out in the international treaties signed or joined by the PRC shall be followed."').

228. Zuigao Renmin Fayuan Guanyü Yijü Guoji Gongyue He Shuangbian Sifa Xiezhu Tiaoyue Banli Minshangshi Anjian Sifa Wenshu Songda He Diaocha Qüzheng Sifa Xiezhu Qingqiude Guiding (最高人民法院关于依据国际公约和双边司法协助条约办理民商事案件司法文书送达 和调查取证司法协助请求的规定) [Provisions of the Supreme People's Court on Handling Requests for Judicial Assistance in Service of Judicial Documents, Investigation and Taking of Evidence in Civil and Commercial Cases in Accordance with International Conventions and Bilateral Treaties on Judicial Assistance] (promulgated by Sup. People's Ct., Apr. 7, 2013, effective May 2, 2013) (Lawinfochina) (China). 
execution of requests through the Hague Evidence Convention for banking records kept in China. ${ }^{229}$ These factors combined, show a willingness on the part of the Chinese government to abide by the provisions of the Hague Evidence Convention.

The approach used in the Tiffany cases also deals better with the inconclusive nature of the evidence regarding the execution of Hague Evidence Convention requests in China. China was faulted for having inadequate information regarding its compliance with Hague Evidence Convention requests, yet it is by no means unique in this regard. In 2003 and 2008, the Hague Conference issued questionnaires regarding the execution of Hague Evidence Convention requests. ${ }^{230}$ The PRC did not respond to either questionnaire, but the information for a number of other states is available, including the United States. ${ }^{231}$ In its response to the questionnaire, the United States claimed it had no system for keeping track of how many Hague Evidence Convention letters of request were actually executed. ${ }^{232}$ The United States also claimed that letters of request can take anywhere from one month to two years to execute. ${ }^{233}$ Given that the United States was unable to provide accurate statistics on the number of requests executed and the average length of time for execution, faulting China for the same lack of information hardly seems appropriate. And while China admittedly did not respond to the questionnaires, the Chinese legal system has been developing rapidly in the past few years. Penalizing China for omissions from several years ago is hardly the best course of action.

Furthermore, China has spent "the past thirty years ... engaged in what is perhaps the most rapid development of any legal system in the history of the world."234 Given this state of affairs, the likelihood that

229. Tiffany (NJ) LLC v. Forbse, No. 11 Civ. 4976, 2012 U.S. Dist. LEXIS 72148, at *19 (S.D.N.Y. May 23, 2012).

230. Publications: Questionnaires \& Responses: Responses Received 2003, HAGUE CONFERENCE ON PRIVATE INT'L LAW, http://www.hcch.net/index_en.php?act=publications.details \&pid=3054\&dtid=33 (last visited Oct. 28, 2014) [hereinafter Publications 2003]; Publications: Questionnaires \& Responses: Responses Received 2008, HAGUE CONFERENCE ON PRIVATE INT'L LAW, http://www.hcch.net/index_en.php?act=publications.details\&pid=4457\&dtid=33 (last visited Oct. 28, 2014) [hereinafter Publications 2008].

231. Publications 2003, supra note 230; Publications 2008, supra note 230.

232. Permanent Bureau, Hague Conference on Private InT'L LaW, Questionnaire of MAY 2008 Relating to the Hague CONVENTION OF 18 MARCH 1970 ON THE TAKING OF EVIDENCE ABROAD 12, available at http://www.hcch.net/upload/wop/2008usa20.pdf.

233. Id

234. Benjamin L. Liebman, Assessing China's Legal Reforms, 23 Colum. J. AsiAn L. 17, 18 
China would have had inconclusive statistics on its history of executing requests is not entirely surprising. However, a number of reforms suggest China may now be better equipped to deal with the execution of Hague requests.

Chinese reforms have led to increased professionalization with better legal education systems, more "legally-trained personnel," and higher professional and educational standards for judges. ${ }^{235}$ Legislation has shifted its focus from economic development to cover a wider range of topics, including public and private law. ${ }^{236}$ Additionally, many of China's legal reforms "have sought to bring China into line with international practice." ${ }^{237}$ Given China's unique position as a developing state with a rapidly developing legal system, courts should not continue to punish China for problems related to its legal system without conclusive evidence of their existence and without ever giving China a chance to rectify those problems. The only way China can fall in line with international practices under the Hague Evidence Convention is if it is given the chance to do so.

2. How the Hague Evidence Convention Can Benefit the United States

The Hague Evidence Convention is also better suited to bridge gaps between United States and Chinese law. The purpose of the Hague Evidence Convention was to eliminate conflicts between common law countries like the United States and civil law countries like China. ${ }^{238}$ While the Convention may have been aimed specifically at evidentiary law, it can also help to address other conflicts-of-law issues like those seen in Tiffany I, Tiffany II, and Gucci. ${ }^{239}$

By using the Hague Evidence Convention, litigants could acquire the information requested without forcing Chinese non-parties to violate domestic Chinese law. The use of a Hague Evidence Convention letter

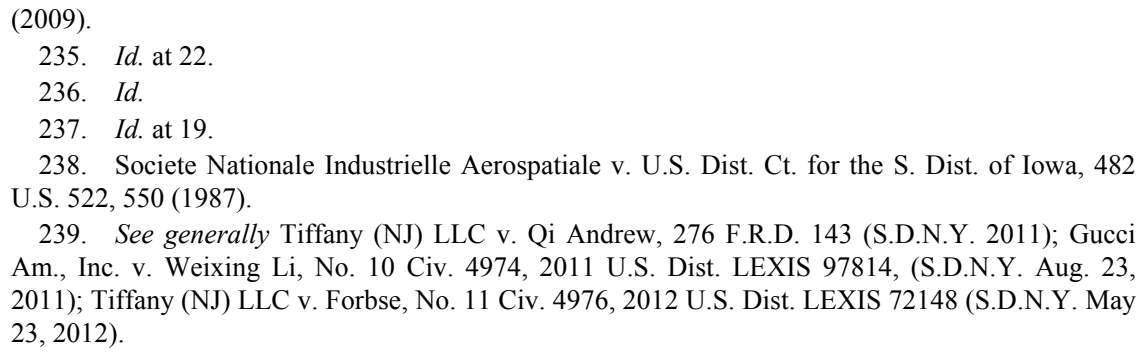

239. See generally Tiffany (NJ) LLC v. Qi Andrew, 276 F.R.D. 143 (S.D.N.Y. 2011); Gucci Am., Inc. v. Weixing Li, No. 10 Civ. 4974, 2011 U.S. Dist. LEXIS 97814, (S.D.N.Y. Aug. 23, 2011); Tiffany (NJ) LLC v. Forbse, No. 11 Civ. 4976, 2012 U.S. Dist. LEXIS 72148 (S.D.N.Y. May 23, 2012). 
of request would put Chinese government authorities in the position to collect the requested information. Letters of request through the Hague Evidence Convention go first to the MOJ and are then transferred to the relevant local court. ${ }^{240}$ Because certain Chinese government authorities (but not foreign courts) can waive bank secrecy laws and collect otherwise confidential information, the use of the Hague Evidence Convention provides a way to legally collect the information plaintiffs need. ${ }^{241}$ If forced to produce evidence under the Federal Rules, however, Chinese banks would be forced to make a choice between noncompliance with a United States court order or risk incurring penalties under Chinese law. As noted in the ABA resolution, such a choice is inconsistent with the general promotion of the rule of law. ${ }^{242}$

Forcing Chinese non-parties to make such a Hobson's choice also works against many of the United States' long-term interests. While the United States has a significant short-term interest in the quick and fair adjudication of suits brought in its courts, it also has a substantial longterm interest in "[furthering and maintaining] the climate of cooperation and goodwill necessary to the functioning of the international legal and commercial systems." 243 By failing to show due respect for the laws of foreign sovereigns, United States courts work against broader United States' interests in this area generally. A lack of respect for China's sovereign interests places strain on the United States' already tense political and economic relations with China specifically. Furthermore, forcing Chinese banks to produce evidence in violation of Chinese law could also discourage Chinese banks or other businesses from setting up in the United States out of fear that United States court orders would force them to violate either domestic or foreign law. ${ }^{244}$

At the same time, United States courts should not forsake the interests of American parties in order to defer to the sovereign interests of states whose legal systems are not particularly transparent. If a state's

\footnotetext{
240. Yu, supra note 1, at 3000 .

241. See generally Zhonghua Renmin Yinhang Guanyü Fabu "Jinrong Jigou Xiezhu Chaxün, Dongjie, Kouhua Gongzuo Guanli Guiding” de Tongzhi (中国人民银行关于发布《金融机构协助 查询、冻结、扣划工作管理规定》的通知) [Notice of the People's Bank of China on Promulgating the Provisions on the Administration of Financial Institutions' Assistance in the Inquiry, Freeze or Deduction of Deposits](promulgated by the People's Bank of China, Jan. 15, 2002, effective Feb. 1, 2002) (Lawinfochina) (China).

242. ABA Res. 103, supra note 153, at 3.

243. Aerospatiale, 482 U.S. at 550.

244. See ABA Res. 103, supra note 153, at 15.
} 
legal system has serious transparency issues and well-established problems executing Hague Evidence Convention requests, United States courts should not have to continue resorting to the Hague Evidence Convention for evidence disclosure as a first resort. Thus, a bright-line rule of first resort may not be an ideal resolution to the problems created by the Aerospatiale ruling. China admittedly does have some transparency issues, but has made significant strides in bringing its legal system in line with international standards. ${ }^{245}$ In such a situation, the holding in the Tiffany cases represents a fair compromise between the interests of a developed state like the United States and a developing state like China.

The Tiffany cases' rulings could also be used to cure a number of common criticisms of post-Aerospatiale jurisprudence. It eliminates the pro-forum bias in court decisions, which has come in the wake of the Aerospatiale ruling and has been roundly criticized. The ruling is also in line with the Hague Conference's recommendation that use of the Convention should be a first priority in the courts of contracting states. ${ }^{246}$ Furthermore, it provides a standard to apply in similar cases, removing the confusion and uncertainty which currently reign in this area.

This is not to say that the analysis in Tiffany I and Tiffany II was without issue. The court still looked to the frequency of sanctions for violating banking secrecy laws in determining China's national interests and the hardship of compliance for the bank. ${ }^{247}$ As noted above, however, if China's banking system is relatively new and the legal system is still developing, the record of enforcement may be scant. This places the banks in the position of having to be sanctioned in order to prove they will be sanctioned. ${ }^{248}$ Moreover, Tiffany II also held that because of large state ownership interests in the banks, it was unlikely that the banks would be sanctioned by the government. ${ }^{249}$ This was in spite of the fact that the banks were able to cite cases in which they had been already sanctioned for unintentionally violating bank secrecy laws. ${ }^{250}$ Despite these issues, the Tiffany cases were still able to reach an

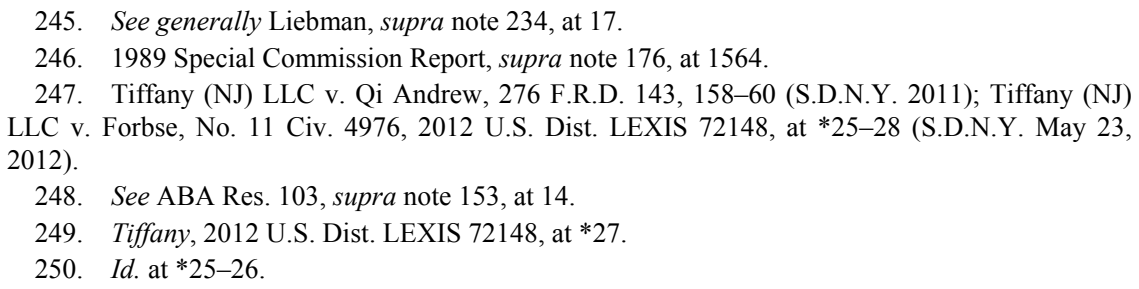


outcome that best balanced the interests of the sovereigns and parties involved.

\section{Guidelines for Compliance}

In order to protect the United States' interest in fully and fairly adjudicating cases, courts should adopt some guidelines in determining whether China has complied with a Hague Evidence Convention request. Two key factors in determining if a request has been successful are the time taken to execute the request and the quality and quantity of the documents produced. ${ }^{251}$ According to the Report of the Special Commission on the Operation of the Hague Convention on the Taking of Evidence Abroad in Civil or Commercial Matters, the average time taken to execute a letter of request internationally was between one to six months. ${ }^{252}$ This average is consistent with a survey of American attorneys who reported the majority of their letters of request had been executed within six months. ${ }^{253}$ Since the MOJ reported that the average time taken to execute requests in China was six to twelve months, ${ }^{254}$ six months should be a workable time frame for China to execute its requests.

China will also need to produce documents of a certain quality and quantity to demonstrate compliance. China's reservation to the Hague Evidence Convention does put limits on what documents the MOJ will produce. ${ }^{255}$ However, this should not necessarily entitle them to refuse to produce documents relevant to United States litigation. When the court in Tiffany $I$ evaluated the success of the letter of request sent under the Hague Evidence Convention, the court determined the request had not been "futile" because the documents produced had disclosed important information. ${ }^{256}$ A general guideline, then, for production of documents is

251. See, e.g., Tiffany (NJ) LLC v. Andrew, No. 10 Civ. 9471, 2012 U.S. Dist. LEXIS 160522, at *7-11 (S.D.N.Y. November 7, 2012) (evaluating the success of a letter of request under the Hague Evidence Convention by addressing the time taken to execute the request and the importance of the documents produced).

252. Hague Conference on Private International Law: Report of the Special Commission on the Operation of the Hague Convention on the Taking of Evidence Abroad in Civil or Commercial Matters, reprinted in 24 I.LM. 1668, 1674 (1985).

253. Report on Survey of Experience of U.S. Lawyers with the Hague Evidence Convention Letter of Request Procedures, 2003 A.B.A. SEC. INT'L LAW \& PRACTICE 10-11.

254. See supra text accompanying note 94.

255. See supra Part II.A.2.

256. Tiffany (NJ) LLC v. Andrew, No. 10 Civ. 9471, 2012 U.S. Dist. LEXIS 160522, at *7-11 (S.D.N.Y. November 7, 2012). 
whether the documents produced disclosed information important to the litigation. If China fails to produce relevant documents or does not do so within the allotted timeframe, courts can then compel disclosure through the Federal Rules.

\section{CONCLUSION}

While some transparency issues remain regarding the judicial assistance and evidence disclosure process in China, the rapid development of the Chinese legal system and the absence of any reliable statistics on execution make accurate determinations of the treatment of Hague Evidence Convention requests difficult. With the increasing commercial interaction between the United States and China, litigation between the states is almost certain to increase. Thus, courts need to have some guiding principle to deal with the rapidly changing state of Chinese law, as well as other nations in China's position.

The Tiffany cases' holdings, that China should be given a chance to execute a letter of request under the Hague Evidence Convention before resorting to the Federal Rules, is the best resolution of the issues presented in these cases. It balances the short-term interests of the United States in adjudication with China's sovereign interests as well as the United States' own long-term interests in international cooperation. The holding also provides an ideal way of dealing with the rapidly changing state of the Chinese legal system by giving China the chance to comply with international standards of practice. Adding some new guidelines on what China must do to comply with Hague Evidence Convention requests will help litigants know what to expect in cases, while upholding the interests of both the parties and sovereigns involved. 